\title{
DA GÊNESE DA TRADUÇÃO LITERÁRIA: UMA COMPILAÇÃO DE ENSAIOS INGLESES DOS SÉCULOS XVII E XVIII
}

\section{Marcelo Módolo* Pedro Mohallem* *}

tradução literária, embora só mais recentemente tenha sido tratada como ciência e prima da literatura, é uma arte milenar. Em 300 a.C, livros do cânone judaico já eram traduzidos para o aramaico com o propósito de serem o mais fiel possivel à obra de partida; Cícero (108 a.C.), contrariando a transposição literal palavra por palavra, manifestava sua preferência pela fluidez e naturalidade do texto traduzido, mesmo que isso significasse não seguir fielmente o texto de partida; Jerônimo de Estridão (São Jerônimo) (4 d.C.), tendo traduzido os escritos judaicos para o latim, permitindo a manutenção e a expansão da Igreja no Ocidente, recebeu o título de padroeiro dos tradutores. É inquestionável que, desde sempre, a literatura precisou da tradução para ser divulgada, atualizar-se e, sobretudo, para sobreviver.

Os Escritos Clássicos Ingleses sobre a Tradução - 1615-1791, organizados por John Milton ${ }^{1}$ e Dirceu Villa ${ }^{2}$, apresentam um compilado de teorias da tradução imprescindiveis para estudiosos e curiosos da área que busquem compreender a gênese da tradução literária com uma base metodológica mais desenvolvida - base essa que viria, com Ezra Pound, a abraçar definitivamente a crítica literária. Se hoje possuímos uma bibliografia maciça de estudos tradutológicos, tudo começou com os franceses e com os autores ingleses desse volume.

\footnotetext{
Universidade de São Paulo (USP) - São Paulo - SP - Brasil. E-mail: modolo@usp.br

** Universidade de São Paulo (USP) - São Paulo - SP - Brasil. E-mail: pedromrd96@gmail.com

1 John Milton é professor titular de Língua e Literatura Inglesa na Faculdade de Filosofia, Letras e Ciências Humanas da Universidade de São Paulo (FFLCH-USP), com especialidade em Estudos da Tradução. Publicou, dentre vários livros, $O$ Clube do Livro e a Tradução (Edusc, 2002) e Tradução: teoria e prática (Martins Fontes, 2010). Traduziu Morte e Vida Severina para o inglês e, para o português, poetas como William Shakespeare, John Keats, William Wordsworth e Percy Bysshe Shelley.

2 Dirceu Villa é poeta e tradutor, com mestrado e doutorado em Estudos Linguísticos e Literários em Inglês pela USP. De poesia autoral, publicou os livros MCMXCVIII (Badaró, 1998), Descort (Hedra, 2003) e Icterofagia (Hedra, 2008); traduziu, dentre outros, Ezra Pound (Lustra, Demônio Negro/Annablume, 2011), Ovídio e E. E. Cummings.
} 
Além do Prefácio do professor John Milton, que traça o panorama e as propostas do livro de maneira clara e objetiva, dividem-se ao longo de 212 páginas alguns textos dos mais reconhecidos tradutores ingleses da época: George Chapman, Sir John Denham, Abraham Cowley, John Dryden, Conde de Roscommon, Alexander Pope, Samuel Johnson, William Cowper e Alexander Fraser Tytler, aos quais se somam excertos retirados de “The Gentleman's Magazine".

Considerações acerca da composição do produto traduzido (George Chapman, por exemplo, critica as traduções que mantêm a eloquência latina na língua inglesa, pois "perdem a graça natural de seu dialeto e envergonham seus autores com glosas forçadas"3), da responsabilidade do tradutor para com o autor (John Denham ${ }^{4}$ condena a função de fidus interpres e prega uma moderada liberdade na transposição do espírito da obra original, de modo que se consiga elevar a fama do tradutor como autor propriamente dito), da fidelidade do texto traduzido, dos níveis de modificação da obra de partida e outras mais são formuladas pelos autores, que parecem discutir calorosamente entre si, discordando, acrescentando, desmentindo-se uns aos outros.

Algumas reflexões soam atuais, como a categorização dos tipos de tradução em metáfrase, paráfrase e imitação proposta por John Dryden ${ }^{5}$, ou ainda a lucidez de Abraham Cowley ${ }^{6}$ ao criticar a tradução palavra-por-palavra de um poema, prenunciando a necessidade de haver engenho (ou wit) e sensibilidade por parte do tradutor antes de uma exatidão vocabular. Há que se priorizar o último ensaio, possivelmente o mais estruturado como ensaio de fato, de Alexander Fraser Tytler ${ }^{7}$, que põe sob jugo crítico traduções dos demais compositores dessa antologia, listando os princípios de uma boa tradução e dando um passo à frente ao estudar a tradução de expressões idiomáticas para o inglês.

O resultado dessa compilação é interessante, pois o fato de ser uma edição bilingue construída por vários tradutores contemporâneos abre ainda novos diálogos com os ingleses. Destacam-se dois textos: "George Chapman, To the Reader of The Illiads of Homer" e "Sir Joh Denham, "To Sir Richard Fanshaw, upon his Translation of Pastor Fido", ambos compostos em pentâmetros iâmbicos rimados. A tradução do primeiro, por Adauri Bezolin, foi feita em prosa livre, primando pelo sentido em detrimento dos ornamentos formais e sonoros. A segunda, de Fernando L. Dantas, manteve a estrutura de versos rimados, sem no entanto preservar o metro regular. Influenciados por projetos de tradução diversos, os responsáveis pela versão em português imprimiram sobre os textos originais sua própria teoria, como o fizeram os próprios autores ingleses, atualizando direta ou indiretamente as discussões propostas por eles.

Os textos de Os Escritos Clássicos Ingleses sobre a Tradução compõem um livro acessivel a todo o meio acadêmico e a entusiastas dos estudos tradutológicos. Trata-se de um documento de grande valor histórico e literário, cujo conteúdo merece ser posto ao lado das teorias de tradução modernas e con-

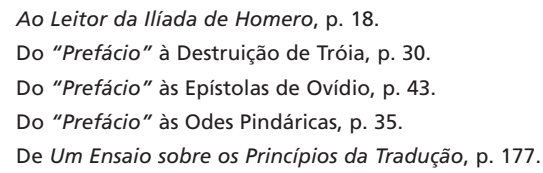


temporâneas; senão para confirmá-las, para ajudar a entendê-las e para sabermos como chegamos aqui. Esses ingleses "deixaram a mesa posta" ao discutirem as principais formas de tradução literária, a correspondência interlingual dos signos e ao dirigirem um olhar atento à importância do tradutor como autor.

Recebido em junho de 2016. Aprovado em agosto de 2016.

\begin{tabular}{||r}
\cline { 2 - 2 } \\
\hline Os Escritos Clássicos Ingleses sobre a Tradução \\
\hline$-1615-1791$. São Paulo: Humanitas; \\
Capes, 2012. $212 \mathrm{p}$. \\
\hline
\end{tabular}

